\title{
リモコンボートを用いた超浅海に扣ける海底地形 扎よび水温プロファイル計測
}

\author{
上村 清二, 小笠原 英子, 森 和義, 中村 敏明 (防衛大学校) ${ }^{* 1}$ \\ 菅 浩伸 (岡山大学) $* 2$ \\ em49047@nda.ac.jp
}

(2011 年 5 月 30 日原稿受付)

\begin{abstract}
:
Of all the factors involved with sound propagation in very shallow water, the water temperature has the greatest effect on the sound velocity. However, there are considerable difficulties in measuring the water temperature in the sea. Therefore, we propose to install a thermister chain in a commercially available remote-control boat with sounding capability. First, we conducted an experiment to compare the measuring function between the remote-control boat and other reference equipment to survey the accuracy of our proposed method. The results confirmed the accuracy of position, sounding, and temperature measurements made by the boat in practical use. Next, we measured water temperature profiles in Hashirimizu port using the remote-control boat system. According to the temperature data, unexpected changes of water temperature were found at different locations and times, caused, we believe, by variations in the air temperature accompanying weather conditions. Finally, we calculated the sound ray trace using actual sea temperature data and confirmed the available path for sound propagation in very shallow water.
\end{abstract}

Classification: 音波伝搬, 海洋構造, その他 (観測, 計測等)

Keyword: 水温プロファイル, 音波伝搬, 超浅海, 海底地形, 音響測深, GPS

\section{1. はじめに}

実海域における長期間の音波伝搬実験を行うた めには, 多くの制約が伴う。まず, 移動や器材の 設置のために，船が必要である，大型の船になれ ば, 操縦手と観測員の他に, 多くの乗組員を必要
とするため, その規模は大きなものとなる. 次に 電源の問題がある. 岸から遠く離れた沖まで電源 を引くことはできないため, 必然的にバッテリー が電源となる，音波伝搬実験では，送波時に多く の電力を必要とすることからバッテリー電源を用

\footnotetext{
Bathymetry and Water Temperature Profile Measured by a Remote-control Boat in Very Shallow Water

* 1 Seiji KAMIMURA, Hanako OGASAWARA, Kazuyoshi MORI, Toshiaki NAKAMURA (National Defense Academy)

* 2 Hironobu KAN (Okayama University)
} 
いた長期間に及ぶ観測は難しい. また,バッテリー 自体の大きさが計測器を大型化させるという問題 もある，他にも，海中に器材を設置するためには 複雑な係留装置が必要であり, その設置のための クレーン等の器材は, 小型船には搭載していない. さらに，一度係留してしまうとデー夕を取り出す ことはできないため,リアルタイムでの值を計測 することは難しい. そのため, 望ましいデータが 取得できたかを知るのは回収後になる。このよう に実海域での実験は，周到な準備と十分な機材が 必要となるため, 実施可能な研究機関は限られる. 一方, 水槽による実験は, 電源の問題もなく, 特 別な器材も必要としないため比較的容易に実施可 能である。そのため, 過去の研究においても実際 の浅海域での環境の再現や理論の妥当性の確認の ために水槽実験は行われてきた ${ }^{1-2)}$ 。しかしなが ら，海洋実験における最大の特徴である自然現象 を同じように再現することはできない．

このような実海域での音波伝搬実験の複雑さ と水槽実験での不足要素を補うものとして Fig. 1 に示す神奈川県横須賀市にある走水港において伝 搬距離約 $120 \mathrm{~m}$ ，平均水深約 $4 \mathrm{~m}$ の超浅海域音波

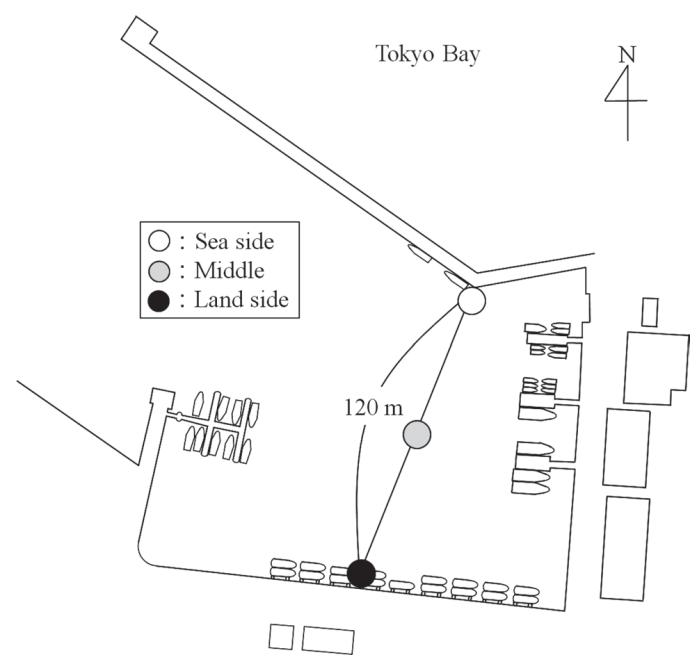

Fig. 1 Map of the experimental area. Equipment used for the reciprocal propagation experiment located in sea side and land side. The three circles show the areas where we measured the water temperature.
伝搬実験を行っている ${ }^{3)}$. 超浅海における実験は, 現在でも数多く行われているが4-6), 平均水深が $5 \mathrm{~m}$ 以下であるものは極めて稀である。この場所 は，東京湾の入口に面しており，堤防によって大 きな波の到達は妨げられるが，潮汐などの海洋現 象及び気象状況は，実海域と同じ条件で実験が可 能である. 実験装置の概要は, 走水港内の両岸に 2 台の音波伝搬装置を設置して双方向から音波を 送受波する。その到達時間を計測することにより 流速や水温を求めるというものである.

双方向音波伝搬実験は, 音響卜モグラフィー実 験 $^{7)}$ の基本であり，送受波を 2 点間相互に行うこ とで計測される到達時間，波形等の差を見ること を目的としている. 当初は, 双方向で計測された 伝搬時間から流速や水温計測を行うことが目的と されていたが ${ }^{8-9)}$ ，現在では内部波や潮汐等の海 洋現象の解明を目的とした研究が盛んに行われて いる ${ }^{10-13)}$.

一方で音波伝搬デー夕の解析のためには，リ ファレンスとなる海底地形デー夕及び水温プロ ファイルデータ, いわゆる Ground truth data 及 び Sea truth dataが必要である。これまでの我々 の実験では，音波伝搬経路の海底深度は，小型の 舟から重りのついたロープを垂らすことで計測 し，水温は，音波伝搬装置を設置した両岸の異な る 3 点の深度で計測した。 しかしながらこれらの 方法は，計測点が十分とは言えない上に，多くの 時間・労力を伴うという問題点があった. 一般的 に, 海底地形の計測には, 音響測深機 ${ }^{14)}$ が, 水 温プロファイルの計測にはサーミスタチェーンが 用いられることが多い ${ }^{15-18)}$ 。そこで音響測深機 能のついた市販のリモコンボートに，サーミスタ チェーンを搭載することで効率的かつ高精度な計 測を行うことを考えた。

本研究では，まず，このシステムの計測精度を より高精度の計測器との比較で検証した。次に, このシステムを用いて, 走水港で計測した海底地 形と水温プロファイルを示し, 水温プロファイル については，気象データと比較することで変化の 
原因を検証した．最後に，そのデー夕を元に音線 計算を行い, 音波伝搬経路の変化について考察し た。

\section{2. リモコンボートの構成}

採用したボートは, 調査用無人リモコンボー トRC-S1 (コデン社製)である。このボートは, 音響測深機と GPS 測位装置を搭載している。リ モートコントローラーは, 無線 LAN を通じて測 深データと航路 (GPS) 測位データのリアルタイ ムの画面表示が可能で, 計測データは PC に出力 することが出来る．比較的小型で運搬も容易であ ることから単独で水質や地形調查を行うことを目 的としている. Fig. 2 (a) に示すボートのサイズ に関しては，全長が約 $1 \mathrm{~m}$ ，重さが $11 \mathrm{~kg}$ である。 また, 最大速度 $2.5 \mathrm{kt}$,, 通信到達範囲 $500 \mathrm{~m}$, 連 続 90 分の観測が出来るため 1 人でも十分に比較 的広範囲の計測を実施可能である. Table 1 は, ボートに搭載された計測器の性能緒元である. 位 置精度は, $1 \sim 2 \mathrm{~m}$, 位置分解能は, 1/1,000 秒, MSAS (運輸多目的衛星用衛星航法補強システム) によるDGPS 方式を用いている。音響測深機の
送受波器はボートの船底に装備されており, 測深 範囲は, $0.5 \sim 60 \mathrm{~m}$, 測深分解能 $0.05 \sim 0.3 \mathrm{~m}$, ビー 厶角 $24^{\circ}$, 使用周波数 $200 \mathrm{kHz}$ である. ビームパ ターンを Fig. $2(\mathbf{b})$ に示した.

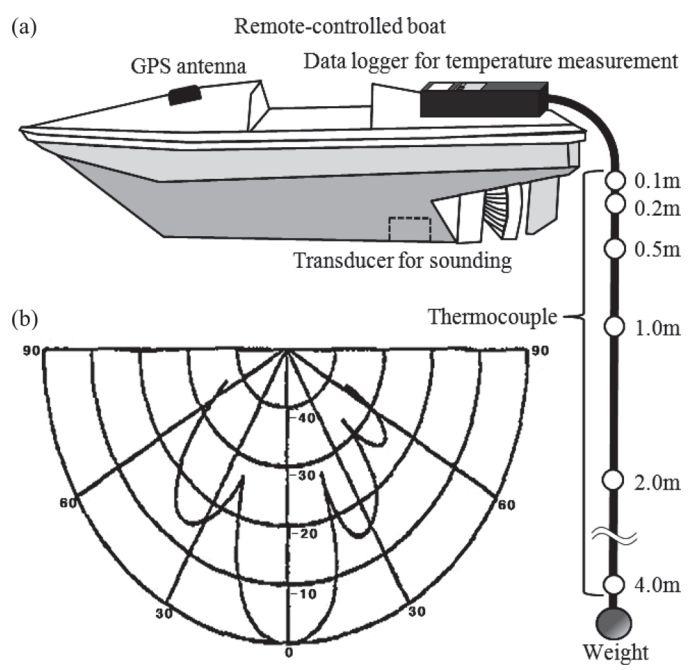

Fig. 2 (a) Schematic depiction of the remote-control boat equipped with a thermocouple. The remotecontrol boat can measure the GPS tracking data, sounding data, and water temperature profile. (b) Beam pattern of the transducer mounted on the remote-control boat.

Table 1 Comparison between boat-mounted devices and reference devices.

\begin{tabular}{|c|c|c|}
\hline GPS & Boat & A 100 \\
\hline Accuracy & $2 \mathrm{~m}$ & $0.6 \mathrm{~m}$ \\
\hline Resolution & $1 / 1,000$ arc-minute & $1 / 1,000$ arc-second \\
\hline \multirow{2}{*}{ Method } & MSAS & SBAS \\
\hline & - & Carrier phase smoothing \\
\hline Sounding & Boat & Sonic2022 \\
\hline Accuracy & $0.04-0.25 \mathrm{~m}$ & - \\
\hline Resolution & $0.05-0.3 \mathrm{~m}$ & $1.25 \mathrm{~cm}$ \\
\hline Beam angle & $24^{\circ}$ & $1^{\circ}$ \\
\hline Frequency & $200 \mathrm{kHz}$ & $200-400 \mathrm{kHz}$ \\
\hline Range & $0.5-60 \mathrm{~m}$ & $\sim 500 \mathrm{~m}$ \\
\hline Beam number & 1 & 256 \\
\hline Temperature & Boat & 600LS \\
\hline Accuracy & - & $\pm 0.15^{\circ} \mathrm{C}$ \\
\hline Resolution & $0.1^{\circ} \mathrm{C}$ & $0.01^{\circ} \mathrm{C}$ \\
\hline Channel & 6 & 1 \\
\hline Thermocouple material & Copper-constantan & - \\
\hline
\end{tabular}


ボートには，水温計も搭載されているが，ボー トの船底 1 点の計測しか行うことができない. そ のため, 熱電対で測定した水温データをデータロ ガーThermic model 2300A (江藤電気社製) で記 録する方法を採用した。データロガーの分解能は $0.1^{\circ} \mathrm{C}$ で，熱電対には銅とコンスタンタン $($ 銅 55 $\%$, ニッケル $45 \%$ の組成合金)を用いた。水温 センサー部は, エポキシ樹脂を用いて防水のため のコーティングを施した。今回の実験では，水温 変化が大きいと思われる水面付近に重点を置き, Thermic の最大計測点数 6 点の深度を $0.1,0.2$, 0.5, 1.0, 2.0, $4.0 \mathrm{~m}$ に設定した. データロガーは, ボートの後部に固定され, 熱電対のケーブルを垂 下させている. また，ケーブルの先端に重りを つけることで計測時にボートを静止させた際に, ケーブルが垂直に保たれるように考慮した．重り については, $100 \mathrm{~g}$ 程度と軽く, 移動時にはボー トからの力を受け, ケーブルと重りは, 海面に対 して水平となる．静止時にケーブルが垂直になる まで 15 秒程度の時間は要するが, リモコンボー トの移動及び浮力への影響は少ない.

\section{3. 精度の検証}

\section{1 精度比較}

計測を行う際には, 各種測定器を用いるが, カ タログ性能ではなく, 実際の性能を押さえておく 必要がある。そのため, ボートに搭載されている 位置, 深度, 水温の測定精度を検証するべく, リ ファレンスとなる計測器との精度比較実験を行っ た. Table 1 は, ボートと各リファレンス計測器 の性能緒元をまとめたものである，比較する計測 器は，どれも緒元上ではボートよりも性能が優れ ている. そのため比較する計測器の值にボートの 值が近ければ，ボートの測定性能は実用的である と言える。

\section{2 位置精度}

位置精度に関してはボートと, 2 個の SBAS（静 止衛星型衛星航法補強システム) 衛星を用いる DGPS 方式の Crescent A100（Hemisphere 社製）
との比較を行った. 位置精度比較のための実験は, 静止時と移動時の 2 回に分けて防衛大学校の敷地 内にて実施した。静止時に関しては，周回を行っ た中心付近に台車を静止させ，10 分間 (600 点) の GPS データを取得した。移動時の実験は，台 車上に A100 とボートを固定し, 防衛大学校内を 手押しの台車で周回する間の GPS データ (975 点) を取得した。この時, 両測器の位置の差による緯 度・経度への影響については無視している。また， $\mathrm{A} 100$ は， 1 秒間に 1 回，ボートは 1 秒間に 3 回 の GPS デー夕を取得するため，ボートのデー夕 に関しては, 3 回の平均值とすることで両データ 数と合わせ, 比較を行った. 緯度・経度を $\mathrm{m}$ 単 位に直すに当たって, 緯度 1 秒を $30.8 \mathrm{~m}$, 経度 1 秒を $25.36 \mathrm{~m}$ として計算している.

静止時の GPS データに関しては, 各計測器の ばらつきを調べるために計測器ごとの標準偏差を 求めた. 静止時の GPS データの比較を Fig. 3 に 示す. Fig. 3(a)は, ボートにより得られたデー夕, Fig. 3(b) はA100により得られたデータである. 並べたグラフは同スケールであり，A100の精度 がボートに比して高いことがわかる.A100 とボー トのデータから緯度・経度方向の標準偏差を求め たところ A100は, $3.36 \mathrm{~cm}, 2.39 \mathrm{~cm}$, ボートは $1.38 \mathrm{~m}, 1.06 \mathrm{~m}$ であった. 続いて, 移動時の GPS データに関しては，2つの計測器から取得した同 時刻の GPS データを比較した。移動時に両計測 器で得られたデータが，Fig. 4である. Fig. 4(a) は，ボートにより得られたデー夕，Fig. 4(b) は A100により得られたデータである. 雨グラフよ り, ボートのデータが, A100のデータよりも粗 いことがわかる. GPS デー夕には，時刻デー夕 も含まれるため, 同時刻における比較が可能であ る. 時刻データを利用して毎秒ごとの 2 つの計測 器の緯度・経度方向の差分を求め, その標準偏差 を求めたところそれぞれ $2.14 \mathrm{~m}, 1.40 \mathrm{~m}$ であった。

\section{3 深度精度}

深度を精度比較するために, 両計測器で走水 港の海底地形を計測した。計測器は, 周波数 400 

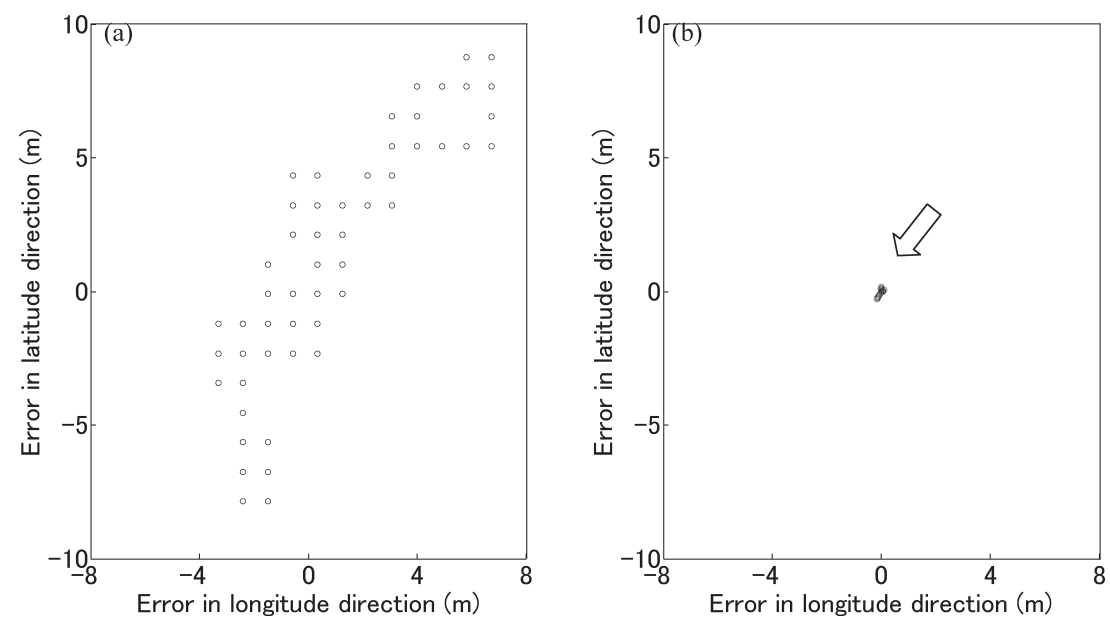

Fig. 3 Comparison of GPS tracking data at rest. The data is saved as the Latitude and Longitude data, but we transform the Lat/Long data into metric data. (a) GPS tracking data measured by the remote-control boat. (b) GPS tracking data measured by the A100. The A100 data is indicated by an arrow.
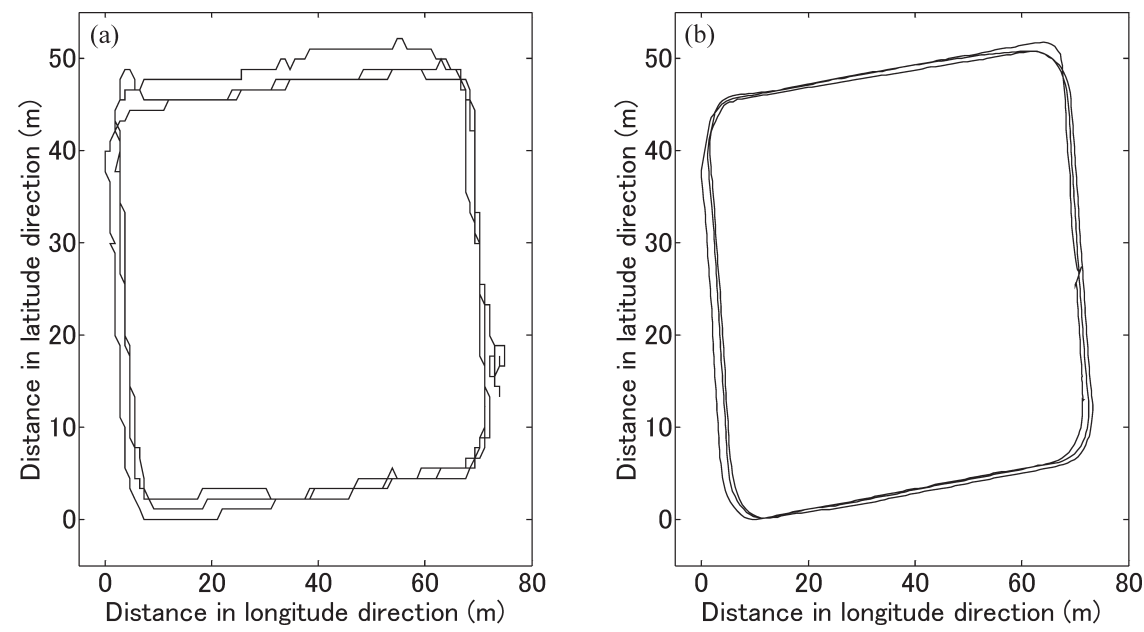

Fig. 4 Comparison of GPS tracking data in moving. The data is showed as metric data, as in Fig. 3. (a) GPS tracking data measured by the remote-control boat. (b) GPS tracking data measured by the A100.

$\mathrm{kHz}$, ビーム幅 $1^{\circ}$, ビーム数 256 本のマルチビー ムソーナーSonic2022 (R2Sonic 社製) と周波数 $200 \mathrm{kHz}$ ，ビーム幅 $24^{\circ}$ のシグルビーム音響測 深機を搭載したリモコンボートである。なお, Sonic2022 の測位装置は, 位置精度実験で使用し た A100同等品を 2 台用いた GPS コンパスで方 位精度は $0.10^{\circ} \mathrm{rms}$ である。また, Sonic2022の 音速補正は，音速計を吊下してプロファイルを計 測して，そこから平均音速を求めて行った，走水 港の概略図を Fig. 1 に示す。先に述べた音波伝
搬実験を行っている経路を測線として海底地形図 から梁度デー夕を取り出し, 両者の深度の比較を 行った. Sonic2022によるデー夕は, 2010 年 11 月 2 日に計測されたものであり, ボートによる データは，2010 年 1 月 $6,8,27$ 日に計測された ものである. ボートのデータは, 3 日間にまたがっ ているが, 潮汐データ ${ }^{19)}$ を用いて日ごとの潮汐 の影響は補正している。 また, 測深と同時に水温 プロファイルを計測した。そのため, ボートの音 速補正に関しては, Mackenzieの式 ${ }^{20)} に$ 計測し 
た水温プロファイルの平均值と平均深度 $2 \mathrm{~m}$, 塩 分濃度 $32 \%$ 。代入して得られた 1 月 6 日 1,495 $\mathrm{m} / \mathrm{s}, 8$ 日 $1,493 \mathrm{~m} / \mathrm{s}, 27$ 日 $1,489 \mathrm{~m} / \mathrm{s}$ という音速 值を用いている.

このようにして得られたボートによる走水港の 海底地形図を Fig. 5, Sonic2022により得られた ものを Fig. 6 に示す。コンターの間隔は，両グ ラフとも $20 \mathrm{~cm}$ であり, 白の破線は, 測線の位置 を示している. ボートの深度デー夕は測線の周辺 を重点的に計測した。また，船の停泊により片側 に関しては岸壁まで計測することができなかった ため, Sonic2022 と比べると計測範囲は狭くなっ ている.さらに，ボートと Sonic2022 のビーム 幅は, 24 と 1 ○であり, 深度が $5 \mathrm{~m}$ であれば水平 分解能は, 約 $2.1 \mathrm{~m}$ と約 $8.7 \mathrm{~cm}$ となる。この約 24 倍の分解能の差は, Fig. 5 と Fig. 6 のグリッ ドサイズ $1.2 \mathrm{~m}, 5 \mathrm{~cm}$ と整合している.

次に, 両計測器で計測した海底地形図から取り 出した測線の比較を Fig. 7 に示す。測線上の深 度の求め方は, 計測されたデー夕を緯度・経度方 向に並べ直し，グリットごとに深度データを与え
た。そして,グリットデータと測線を重ね合わせ， グリットの交点上を通らないものについては, 直 近のデー夕を線形補間して深度を求めた。 その結 果, ボートのデー夕は海底地形の概略を捉えては いるものの Sonic2022に比べると粗い形状を示 した.この 2 つの測線の深度デー夕の差分の平均 值は, $44.58 \mathrm{~cm}$ であった。ボートの測深精度に 関しては, 防衛大学校の大型水槽 (水深約 $5 \mathrm{~m}$ ) に おいて，巻き尺を用いて精度確認試験を行い, 次 式の換算式を得ている.

$$
D_{1}=0.25+D_{2}(\mathrm{C} / 1500)
$$

実際の水深 $\left(D_{1}\right)$ は, 音速 $(C)$ を基準音速 $(1,500$ $\mathrm{m} / \mathrm{s})$ で割ったものに出力された水深 $\left(D_{2}\right)$ を掛け, 補正值 $(0.25)$ を足すことで求められる。 したがっ て, 音速補正, 潮汐補正が正確に行われていれば, $\mathrm{cm}$ オーダーの精度が得られるはずである.今回 のSonic2022 との差の原因は, これらのリファ レンスデータの誤差, あるいはSonic2022の梁 度換算誤差等が考えられる。そこで, 単純に海底

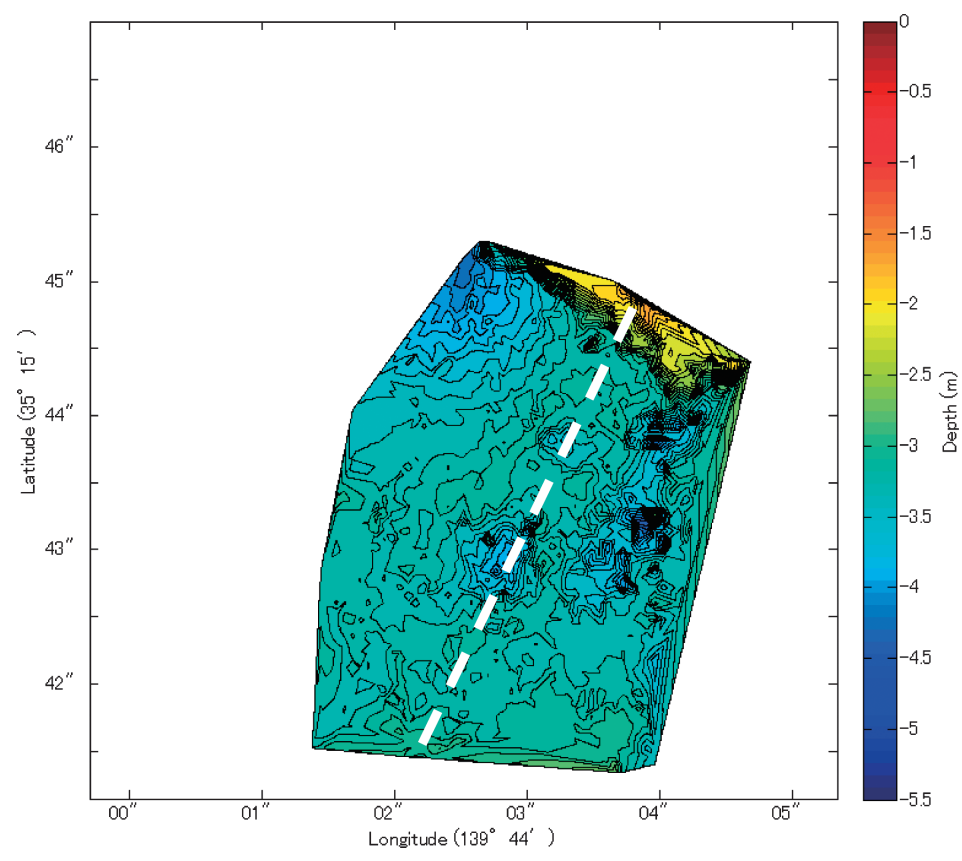

Fig. 5 Bathymetric chart of Hashirimizu port measured by the echo sounder of the remote-control boat. The dashed line is a survey line. We conducted a reciprocal sound propagation experiment on the survey line. 


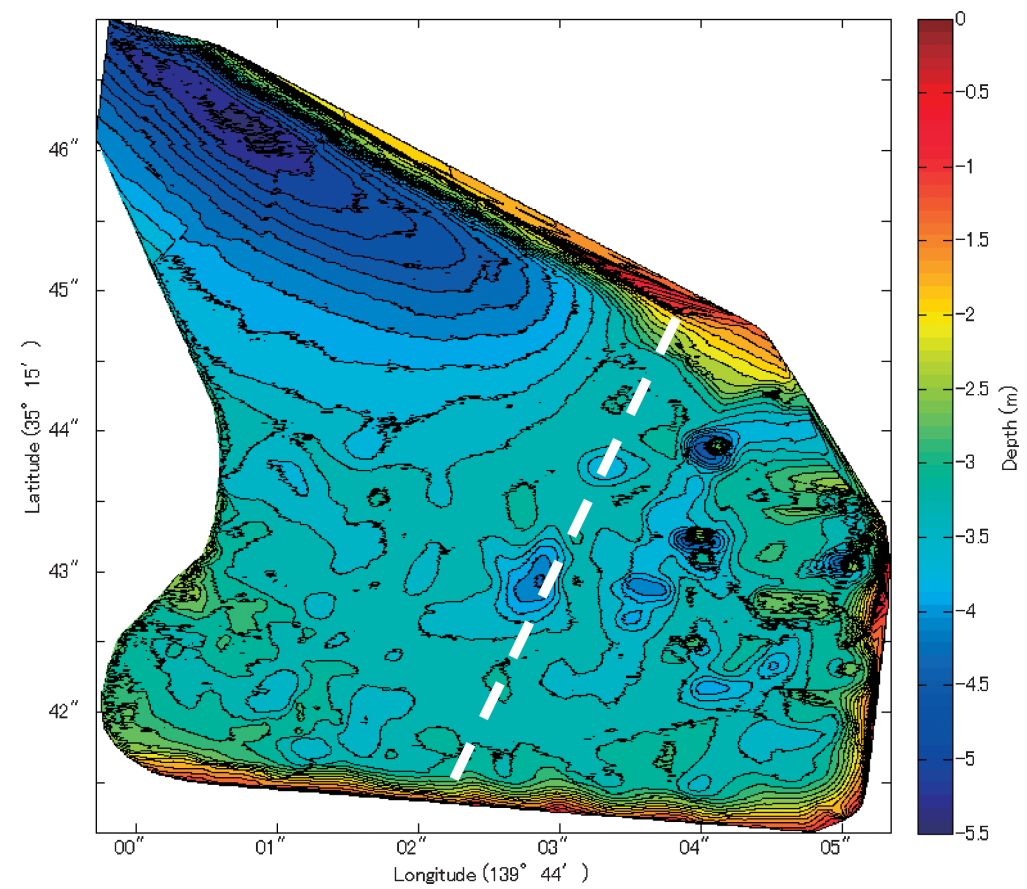

Fig. 6 Bathymetric chart of Hashirimizu port measured by a multi-beam echo sounder, the Sonic2022. The dashed line is a survey line.

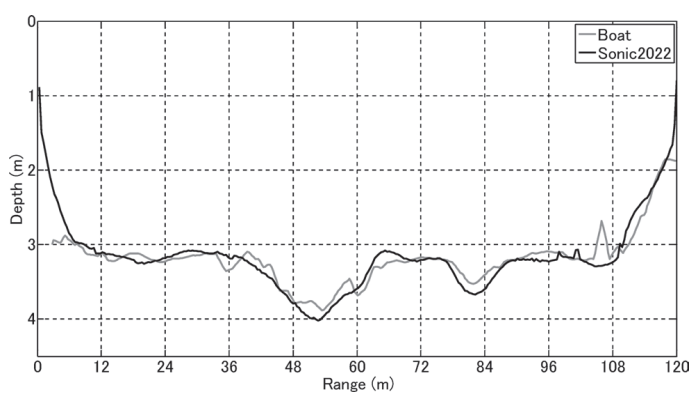

Fig. 7 Comparison of depth between the remotecontrol boat and the Sonic2022 by sounding data along the survey line. The beam angle of the boat and the Sonic2022 was $24^{\circ}$ and $1^{\circ}$, respectively. Therefore, the data of the boat is rougher than that of the Sonic2022.

形状の違いを比較するため, 深度差を補正し, 差 分の標準偏差を求めたところ $12.37 \mathrm{~cm}$ という結 果であった。この結果から海底形状に関しては精 度の良いデータが取得出来ていると考えられる。

\section{4 水温精度}

CTD (塩分・水温・深度計) 600LS (YSI 社製) とボートに搭載されている熱電対で計測した水温
を比較した. 実験方法は, 水槽に両計測器のセン サー部を沈め, 十分に時間を置き, 最初に 5 分間 の計測を行った。この值は, 計測器間のバイアス 補正值として利用した。 その後, 1 分間かけて熱 湯を注入し, 水温を上昇させた後, 自然に水温が 低下する様子を計測した. 熱電対のデータは, デー タロガーの最大チャンネル数である 6 点の計測水 温を平均し，1つの值としたものである. 一方で, 6 点のセンサー毎のばらつきがないか調べるため に同一水槽内の水温を計測した。計測した 6 点の 平均值と 1 点ずつの標準偏差を調べ, 最大と最小 の差を計算したところ $0.0064^{\circ} \mathrm{C}$ であった。この ためセンサー毎の補正は行わなかった.

補正後の水温デー夕の比較を Fig. 8 に示す. 1 分間の熱湯注入によって水温を上昇させたが，そ の直後の計測水温変化に差異が見られた。 ボー 卜は全ての水温の変化に対してリニアに反応し たのに対し, $600 \mathrm{LS}$ は $30^{\circ} \mathrm{C}$ 以上の水温の変化に 追随していないことがわかる。この原因として， 


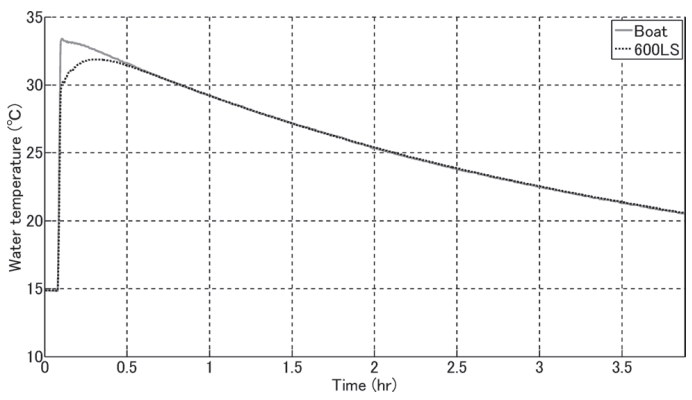

Fig. 8 Comparison of the transient response of water temperature between thermocouple for the remote-control boat and the 600LS. We measured water temperature in the same tank using two types of equipment. After 5 minutes from the start of measurement, hot water was put into the tank.

600LS の内部回路の非線形性が考えられる.こ のことは, 夏期の海面付近の水温が $30^{\circ} \mathrm{C}$ を超え る場合に時間応答が遅れる要因となりうる。一方 で，ボートに採用した熱電対は，水温が $30^{\circ} \mathrm{C}$ 以 上であってもタイムラグなくその場の正確な水温 を捉える事が出来るため, 超浅海域における水温 分布の微細構造を調べる計測に適していると言え る。

また, 計測開始 45 分後から計測終了までのボー トから 600LS を差分した值の標準偏差は $0.032^{\circ} \mathrm{C}$ であった。

\section{4. 水温計測実験および考察}

\section{1 水温計測実験}

ボートによる計測システムを実海域で運用する ための Sea trial として, 走水港においてボート による水温プロファイル計測実験を行った。実 験海域の概略図を Fig. 1 に示す. 3 つの異なる円 は, 海側, 中間, 陸側の 3 点の水温計測地点を示 している. 水温計測実験は，いずれも 2010 年 12 月数日間の $8: 30,13: 00,16: 30$ 頃行われた. 計 測時間は, 1 点につき 3 分間ずつの計 9 分間であ る. 全ての計測を移動時間も含めて 15 分以内で 行なっており，時間に伴う水温差は少ないと思わ れる。
また，計測深度に関しては，熱電対のケーブル 長で定めているため, 強風により海面に波が発生 した時には、リモコンボートがピッチングまたは ロールリングし, 計測深度は変化すると思われる。 平均風速が $5 \mathrm{~m} / \mathrm{s}$ を越える強風の日に行った目視 での観測によると，ローリング方向には 1 秒程度 の周期で舷側で $5 \mathrm{~cm}$ ほど動摇し，ピッチング 方向には 2 秒程度の周期で船側で $\pm 5 \mathrm{~cm}$ ほどの 動摇をしていた，熱電対は，ローリング方向に対 して中心付近に取り付けてあるのでローリングに 伴う動摇の影響は少なく, ピッチング方向に関し ては, 3 分間の動摇の中で計測を行っているため 強風時においては, 設定深度 $\pm 5 \mathrm{~cm}$ 程度の範囲 内で平均化が行われていると考えられる.

\section{2 考察}

\subsection{1 水温プロファイル}

Fig. 9 は, 12 月 3 日, 10 日, 17 日, 20 日, 22 日, 27 日 13:00 頃の走水港内の音波伝搬測線上 3 地 点の水温プロファイルである. まず, 場所ごとの 変化について調べてみると, プロファイルの傾向 は類似しているが, 12 月 20 日の深度 $1 \mathrm{~m}$ 以浅, 12 月 22 日の深度 $2 \mathrm{~m}$ 付近および 12 月 27 日の深 度 $2 \mathrm{~m}$ 以浅のように場所によって $1^{\circ} \mathrm{C}$ 近い変化 が起こることがわかった. しかし, 水温変化が大 きい深度以外のプロファイルを見てみると, 水温 差が少ないことが多く, 局地的な水塊による水温 の違いが現われていると推測できる. また, 日ご との変化に注目すると, グラフが示すように同季 節の同時刻にも関わらず，様々な形状のプロファ イルが観測された. 本論文には記載していないが, 同じょうに朝, 夕の日ごとの変化についても調べ たところ, 水温が 1 日の中で最も上昇する昼ほど ではないが, 日ごとの変化が確認された。

これらの結果は, 時間・場所の違いによる複雑 な温度構造の存在を示している. そのため, 超浅 海域においては，時間・場所を変えた頻度の多 い計測を行う必要があり，容易に運搬が可能でリ モート操作により計測場所の移動を円滑に行うこ とができるリモコンボートによる水温計測は, 有 

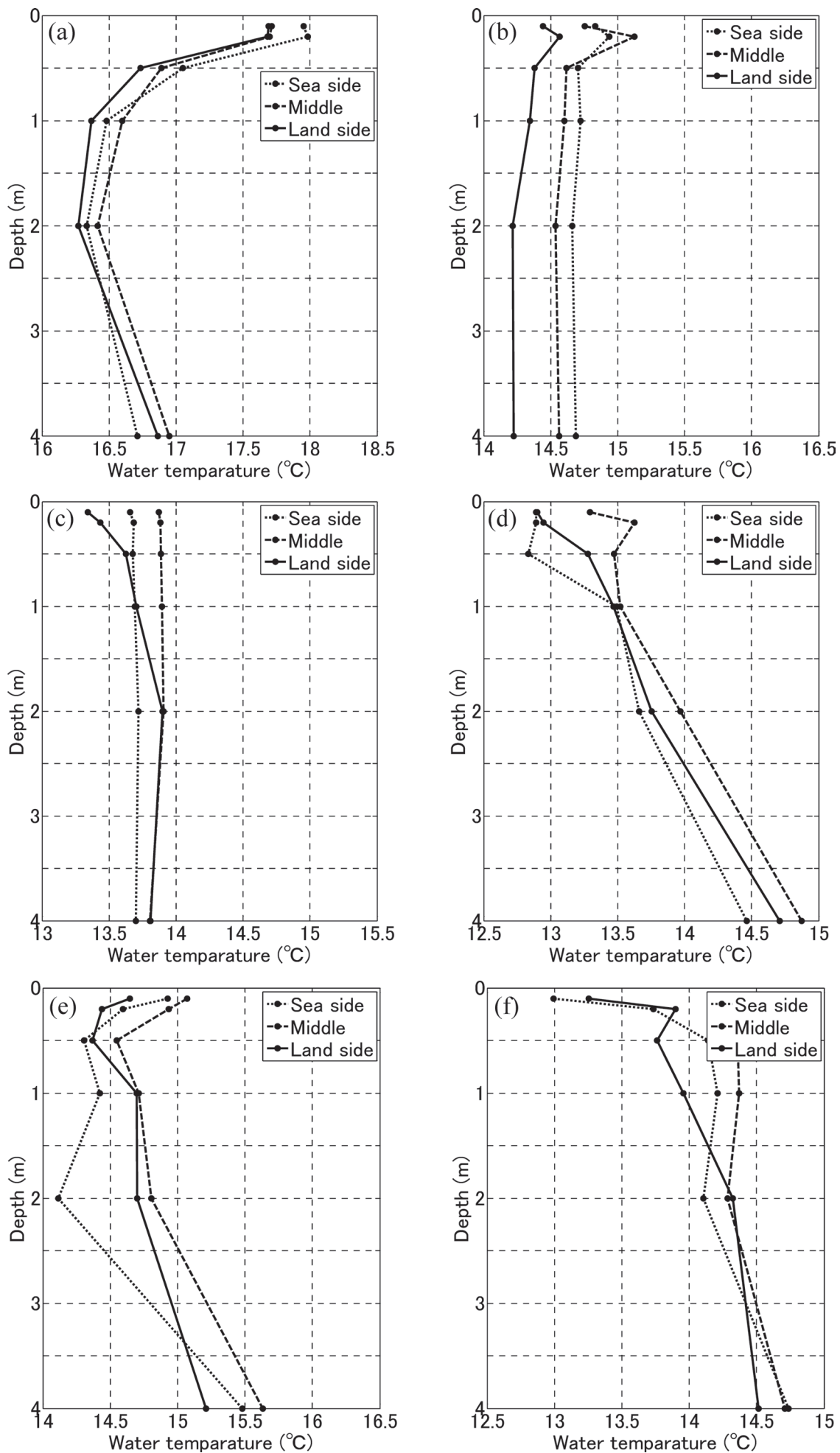

Fig. 9 Water temperature profiles of 6 days in the same month at approximately 13:00: (a) 12/3, (b) 12/10, (c) 12/17, (d) $12 / 20$, (e) $12 / 22$, and (f) $12 / 27$, measured at the sea side (dotted line), in the middle (dashed line), and at the land side (solid line). 
効であると言える。

\subsection{2 気象条件との比較}

4.2.1では, 日ごとの水温変化について述べた が，この原因を考えると超浅海域が，大気と接し ており，特に局地気象による影響が大きいためだ と思われる。 そのため, 水温変化と気象条件の 関係について考察を行った. Fig. 10 は, 2010 年 12 月 22 日の各種気象データ ( (a) 気温, (b) 風速, (c) 降水量, (d) 湿度, (e) 日射量, (f) 気圧) であ る。これらの気象デー夕は, 走水港から距離約 $1,500 \mathrm{~m}$, 高度差約 $110 \mathrm{~m}$ の場所にある防衛大学 校の施設の屋上で計測されたものである。朝 8:30 頃, 昼 13:00 頃, 夕 16:30 頃の 3 回の水温計測が 行われた時刻を各グラフに破線で示した。破線の
太さは，実際の計測時間でグラフ上の横軸の時間 に対応している. 12 月 22 日の天気の概要は, 夜 半から強風と強い雨が降り, 明け方に寒冷前線が 関東地方を通過するまで降り続いた。その後気温 は上昇し，東日本以西では 11 月並の最高気温を 記録した。

Fig. 11 は, 同日の水温プロファイルである. 朝, 昼, 夕に海側, 中間, 陸側の 3 地点で 3 回の計 測を行ったものであり， 3 地点の水温を平均して 異なる 3 つの時間の水温プロファイルを示してい る. 当初, $2 \mathrm{~m}$ から $4 \mathrm{~m}$ に注目すると, 傾きはほ ほ同じで大きな変化は見られない。このことは, $2 \mathrm{~m}$ 以深の水温は, 水温変化はあるものの大気に よるプロファイル形状の変化を受けにくいことを
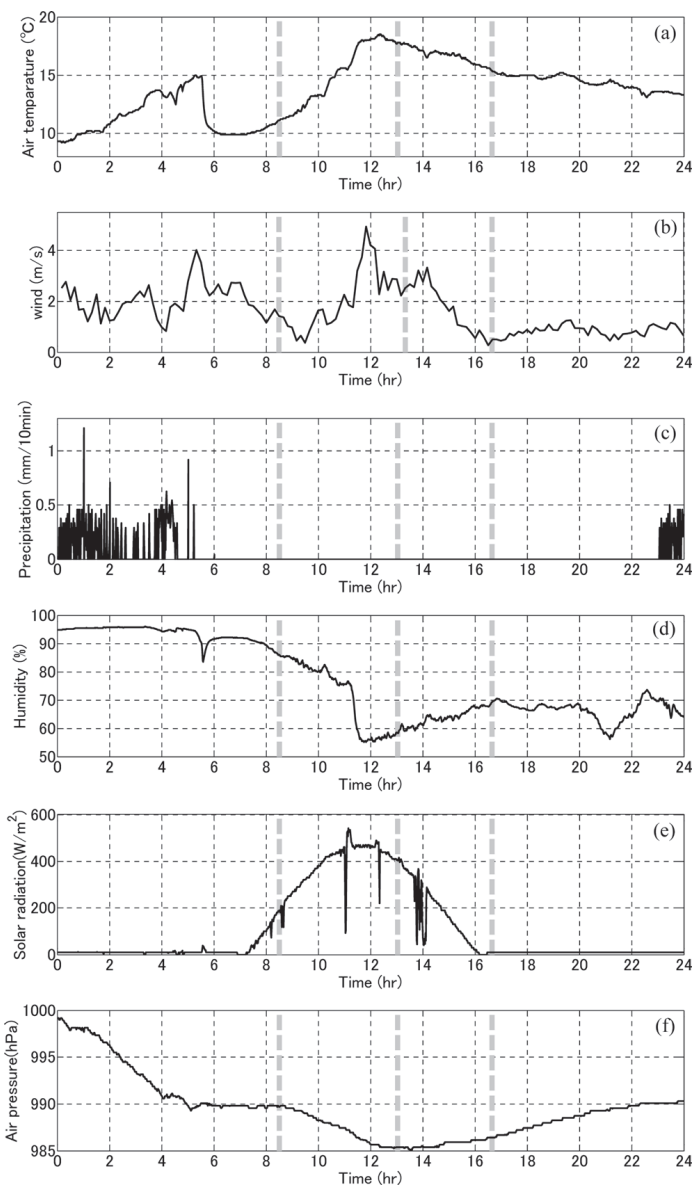

Fig. 10 Meteorological data measured on 12/22 near Hashirimizu port. (a) Air temperature, (b) wind speed, (c) precipitation, (d) humidity, (e) solar radiation, and (f) air pressure. The dashed line shows the time of measuring the water temperature profile in Hashirimizu port. 


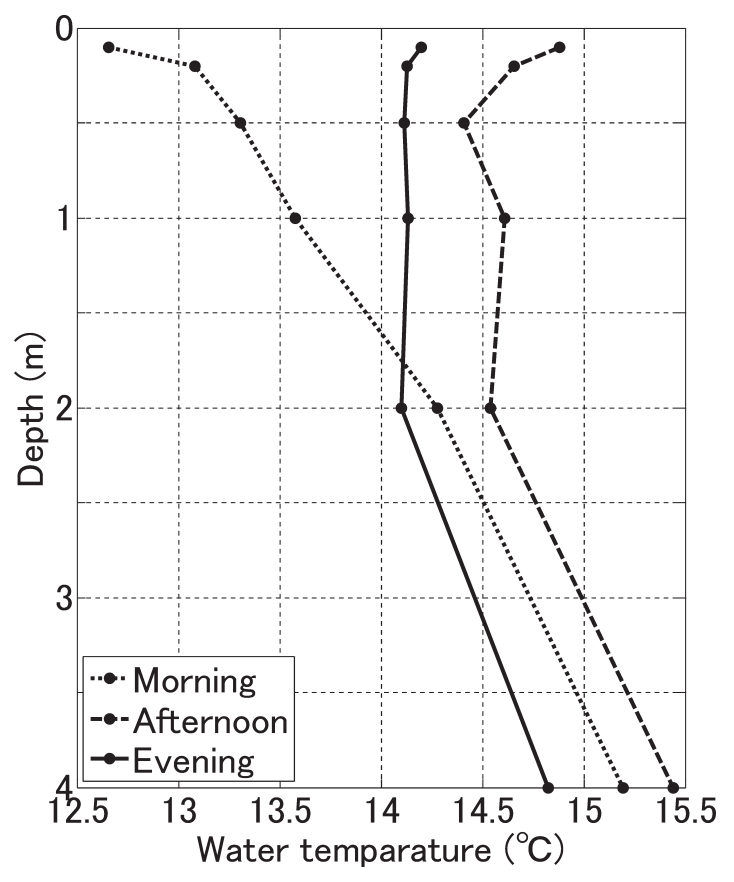

Fig. 11 Water temperature profiles on $12 / 22$ in the morning: around 08:30 (dotted line), afternoon: around 13:00 (dashed line), and evening: around 16:30 (solid line).

示している. 続いて, 深度 $0.1 \mathrm{~m}$ から $2 \mathrm{~m}$ におい ては，朝，昼，夕で異なる形を示している。朝に 関しては，正の勾配を示しており，海面の水温が 低く, 深くなるにつれ水温が高くなる様子が見ら れる。これは， 6 時前に寒冷前線が通過し，短時 間で $5^{\circ} \mathrm{C}$ の気温が低下したことにより，海水が 大気によって冷やされたためと考えることができ る. 6 時前に観測された湿度と気圧の変化は，前 線通過によるものである。 また，昼に計測された 水温プロファイルでは, 正午頃に発生した強風に より海水が擋拌されプロファイルは, 垂直に近づ いたが，日射量増加に伴う気温の上昇により，海 面付近が温められ, $0.1 \mathrm{~m}$ から $0.5 \mathrm{~m}$ において負 の勾配となっている. タのプロファイルでは, 気 温は日の傾きとともに徐々に低下したため, 海面 付近の水温低下によって負の勾配から垂直なプロ ファイルに変化したと推察できる。このように走 水港のような超浅海域では, 水温変化は大気にお ける局地気象の影響を受けやすい。このため, 気
象条件を考慮に入れることは, 水温のパラメータ の影響が大きい音速計算や音波伝搬モデルを考え る際に重要である。

\subsection{3 音線計算}

実測された水温プロファイルから音線計算を 行い, 音波伝搬経路を調べた。計算に関して は, Ocean Acoustics Library ${ }^{21)}$ に配布されてい る AcTUP V2.2L を用いて計算を行った。この プログラムは, Australian Defence Science and Technology Organisation (DSTO) 所属の Amos Maggi Alec Duncanによって提供されている プログラムである。このプログラムに用いた音 速は, Mackenzie の式 ${ }^{21)}$ を用いて計算した。塩 分濃度の值は, 水温計測実験を行った 2010 年 12 月の CTD データの塩分濃度が概ね $29 \sim 31 \%$ の 範囲であったことから一律 $30 \%$ を代入した。 な お, $4 \mathrm{~m}$ から $7 \mathrm{~m}$ の水温に関しては, $2 \mathrm{~m}$ から $4 \mathrm{~m}$ の水温プロファイルの傾きを適用した外挿值 を用いている. 計算の設定は, 最大放射角 $\pm 22.5^{\circ}$, 伝搬距離 $120 \mathrm{~m}$, メッシュ $5 \mathrm{~cm}$ 刻みである。ビー ムは送波器より500 本を放射させているが，そ の中で受波器に到達する固有音線のみを取り出 し, 表示させた. 海面は, 波のない水平な状態で, 送受波器の深度は, 各時刻における潮汐補正值を 考慮した上で海底から $1 \mathrm{~m}$ 上方に設定した。この ような条件で計算を行ったところ， Fig. 12 のよ うな結果を得た。（a) 12月 22 日の朝 08:30 頃，(b) 昼 13:00 頃, (c) 夕 16:30 頃の 3つのグラフは, 実測された Fig. 11 の水温プロファイルデータに 対応している.この結果から, 音線のパターンを 大きく分けると

(1)多重海底海面反射による経路(Fig. 12(a)〜 (c))

(2) 海面反射経路 (Fig. 12(a)，(c))

（3）反射を伴わず到達する経路(Fig. 12(b)，(c)) の 3 つに分類された.

これら経路の発生理由を Fig. 11 の水温プロ ファイルから考察すると, (a)の朝 08:30 頃は, 音源深度が約 $1.9 \mathrm{~m}$ であり, ほぼ直線的な正の勾 

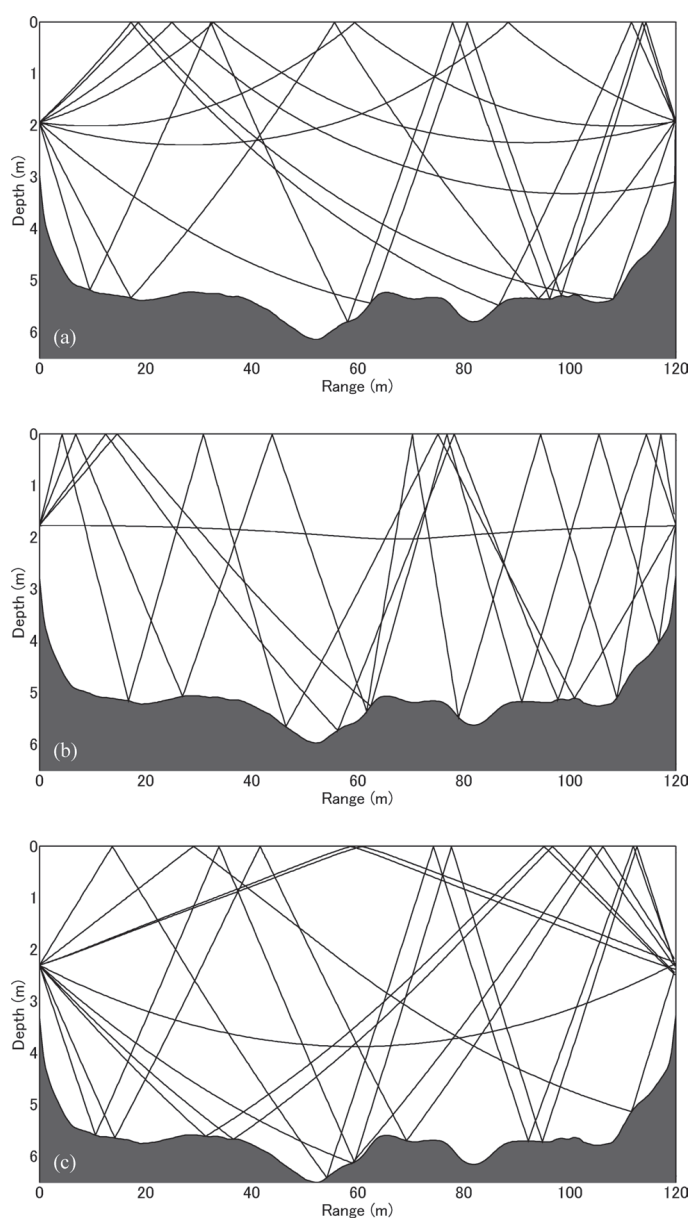

Fig. 12 Eigen ray trace simulations calculated by the profile of Fig. 11. (a) Morning, (b) afternoon, and (c) evening of $12 / 22$. The depth of transducers is corrected by tide data.

配の中にある。そのため, 音線は上方に屈折し, 海面反射経路が生じた。（b）の昼 13:00 頃は，音 源深度が約 $1.8 \mathrm{~m}$ で，等温層の中にある。そのた め, 水平の伝搬経路となった。（c）の夕 16:30 頃 は，音源深度は $2.3 \mathrm{~m}$ で，正の勾配の中であるた め, 下向きに出た音線は上方に屈折した。 また, $2 \mathrm{~m}$ 以浅は等温層のため, 上方に向かった音線は, 直線的に海面に向かい, 測線の中央付近で反射し, 受波点に到達したと考えられる。

以上のように，わずか 1 日の間でも多様な伝搬 経路の変化があることが分かる.

ところで, 音波伝搬実験の目的は, 到達時間を
計測し，逆問題を解くことで海洋パラメータをモ ニタリングすることである. しかし, 走水港のよ うな超浅海域においては, 狭い領域で音波を送受 波するため, 到達時間計測に必要な音波同士が多 重反射し，干渉しやすい，そのため，様々な経路 が観測されるが，それぞれの経路の分離が困難で あるという問題がある. しかし, その反面, 超浅 海域でのモニタリングを行う利点も挙げられる. それは，自然環境にありながら実験に適した環境 であるということである。実験に適していると は, 電源の確保が可能で, 計測器の不具合に対応 しやすいため, 長期の計測が容易であるというこ とである. 通常, このような環境条件は, 屋内に おける水槽実験に限定され, 水温変化に伴う温度 躍層, 海流による流れの影響, 潮汐による深度変 化, 風の影響及び塩分濃度の变化等の自然現象は 再現出来ない. しかしながら, 超浅海域のような 陸地に面した場所では，これらの自然現象が含ま れる上に, データとしての取得が容易なため, 自 然現象がリファレンスデータとして使用できると いうメリットがある. 海洋実験においても継続的 にリファレンスデータを取得することは困難であ るため, 様々な要素を含んだ多角的な考察を行う 上でこのような環境は最適である。 そのため, 将 来的に沿岸域，あるいは外洋における本格的な卜 モグラフィー実験を行う上でのスケールモデル実 験としても適当であると考えられる.

今回は, 音線理論を用いて伝搬経路の計算を 行ったが，その手法には限界がある。 そのため, さらに詳細な解析を行うためには, 波動論を用い たシミュレーションが必要である。一方で, 超浅 海域では計算対象となる範囲が狭いため, 計算領 域が少なくて済むという特徴がある。このことを 考慮すると, 超浅海域での音波伝搬の実験結果を 解釈し，その特性を明らかにするためには，計算 量は比較的大きいが，時系列での音圧・波形を 求められる FDTD (Finite difference time domain) 法を用いた解析が今後の課題として挙げられる.

以上, 超浅海域では, 気象条件により様々な水 
温プロファイルが存在すること, そしてその水温 プロファイルの変化により伝搬経路が異なること について述べてきた，しかし，現在のところ，伝 搬経路の分離が困難であり，将来的に超浅海域で の海洋パラメータのモニタリングを実現させるに は, さらに多くの時間・場所でのリファレンス デー夕を取得し，それらのデー夕を用いて波動論 的な解析を行うことが求められる. そのためには, 多くの計測を行う必要があり, 従来の計測方法で の困難を克服し, 容易な計測を可能としたリモコ ンボートによる計測は，有効な手段となり得るだ ろう。

\section{5. まとめ}

超浅海音波伝搬実験を行う際に必要となる海底 地形及び水温プロファイル計測の容易化を目的と して音響測深機能のついた市販のリモコンボート に, サーミスタチェーンを搭載することを考案し, 実用化のために様々な考察を行った. このシステ ム搭載の計測器と, より高精度の計測機能を持つ 計測器を比較したところ, 位置精度, 測深精度, 温度精度ともに, 実用的な精度であることを確認 した。

次に, 走水港の水温プロファイルを計測した結 果, 予想以上に時間および場所による変化が大き いことがわかった，この変化の原因は, 気象条件 が変化することにより気温が変化し，これが大気 を通じて水温変化として伝わったものと推測され る. また，風による擾乱の影響も考えられる.

最後に, これらのデータを基に音線計算を行っ た結果, わずか 1 日の間でも様々に変化する伝搬 経路が確認された。これらの結果は, 超浅海域音 波伝搬実験の目的としている海洋パラメータのモ ニタリングを行う上で重要な指針を与えるもので ある。

今後は, 波動論的な解析を行うことを目指して さらに多くの時間・場所での水温デー夕を収集 し, 超浅海域における音波伝搬特性の理解を図る.

\section{謝辞}

海上での計測実験の協力をして頂いた防衛大学 校走水海技訓練場の方々およびリモコンボートに よる海底地形デー夕の提供をしてくれた防衛大学 校地球海洋学科卒業生の山田克君には, 深く感謝 申し上げます。

なお, Sonic 2022 を用いた海底地形計測には 平成 $22 \sim 24$ 年度文部科学省科学研究費基盤研 究(A) 22240084 (研究代表者：菅浩伸)によって 岡山大学へ導入された機材を使用した.

\section{参照文献}

1) W. C. Knudsen, "Propagation of a pressure transient in a two-layer liquid model," J. Acoust. Soc. Am., 29(2), 918-924 (1957).

2) A. B. Wood, "Model experiments on sound propagation," J. Acoust. Soc. Am., 31(2), 1213-1235 (1959).

3) H. Ogasawara, K. Mori and T. Nakamura, "Reciprocal sound propagation experiment in very shallow water area of Hashirimizu port," Jpn. J. Appl. Phys., 49 (2010) 07HG15O.

4) O. Bergem, N. G. Pace and D. Dilorio, "Surface wave influence on acoustic propagation in very shallow water," Proc. OCEANS '99, 1, 434-438 (1999).

5) M. Chitre, S. H. Ong and J. Potter, "Performance of coded OFDM in very shallow water channels and snapping shrimp noise," Proc. OCEANS '05, 2, 996-1001 (2005).

6) M. B. Porter and M. Siderius, "Acoustic propagation in very shallow water," Water. Sec. Conf. 2010 Int., 2, 1-4 (2010).

7) W. Munk, P. Worcester and C. Wunsch, Ocean Acoustic Tomography (Cambridge Univ. Press, New York, 1995), p.433.

8) P. F. Worcester, "Reciprocal acoustic transmission in a midocean environment," J. 
Acoust. Soc. Am. 62 (2), 895-905 (1977).

9) H. A. DeFerrari, H. B. Nguyen, "Acoustic reciprocal transmission experiments, Florida straits," J. Acoust. Soc. Am. 79(1), 299-315 (1986).

10) B. D. Dushaw, P. F. Worcester, B. D. Cornuelle and B. M. Howe, "The internal tide of the Western North Atlantic observed using long-range reciprocal acoustic transmissions," J. Acoust. Soc. Am. 97 (3), 3263 (1995).

11) P. F. Worcester, "Ocean current and vorticity measurements using long-range reciprocal acoustic transmissions," J. Acoust. Soc. Am., 100 (3), 2564 (1996).

12) H. Ogasawara, T. Nakamura, H. Fujimori, $H$. Hachiya and K. Mizutani, "Analysis of tidal effect on reciprocal sound propagation in Central Pacific Ocean," Jpn. J. Appl. Phys., 47, 4349-4353 (2008).

13）上村清二, 佐藤壮真, 山田 克, 小笠原英子, 森 和義, 中村敏明, "小規模な双方向伝搬 実験における流れの影響, " 第 31 回超音波 エレクトロニクスシンポジウム講演論文集, 585-586 (2010).
14）海洋音響学会編, 海洋音響の基礎と応用(成 山堂書店, 東京, 2004), p. 173.

15) L. Lieberman, "Effect of temperature inhomogeneties in the Ocean on the propagation of sound," J. Acoust. Soc. Am., 23, 563-570 (1951).

16）奥村康昭, "湖沼水温観測用サーミスタチェー ン計測, " 自動制御学会論文集, 27(5), 614-616 (1991).

17）馬場礼子, 遠藤修一, 下田 力, "ADCP と サーミスタチェーンによるびわ湖の流況の 連続観測, "日本陸水学会大会講演要旨集, 121-122 (1999).

18）磯田 豊, 斉田季実治, 鈴木 恒, "噴火湾 石倉沖の数日周期水温変動, " 沿岸海洋研究, 39(2), 151-161 (2002).

19）第三管区海上保安本部海洋情報部, http:// www1.kaiho.mlit.go.jp/KAN3/.

20) K. V. Mackenzie, "Nine-term equation for sound speed in the Oceans," J. Acoust. Soc. Am., 70(2), 807-812 (1981).

21) Ocean Acoustics Library, http://oalib. hlsresearch.com/. 